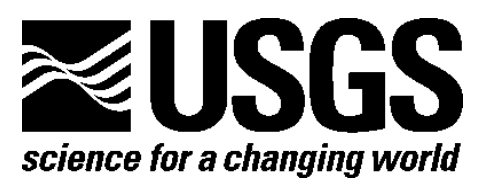

Prepared in cooperation with the Missouri Department of Natural Resources

Bathymetric Maps and Area/Capacity Tables of WaterSupply Reservoirs for the City of Cameron, Missouri, July 2013

By Richard J. Huizinga

Open-File Report 2014-1005

U.S. Department of the Interior

U.S. Geological Survey 


\section{U.S. Department of the Interior \\ SALLY JEWELL, Secretary}

\section{U.S. Geological Survey \\ Suzette M. Kimball, Acting Director}

U.S. Geological Survey, Reston, Virginia: 2014

For product and ordering information:

World Wide Web: http://www.usgs.gov/pubprod

Telephone: 1-888-ASK-USGS

For more information on the USGS-the Federal source for science about the Earth,

its natural and living resources, natural hazards, and the environment:

World Wide Web: http://www.usgs.gov

Telephone: 1-888-ASK-USGS

Suggested citation:

Huizinga, R.J., 2014, Bathymetric surveys and area/capacity tables of water-supply reservoirs for the city of Cameron, Missouri, July 2013: U.S. Geological Survey Open-File Report 2014-1005, 15 p., http://dx.doi.org/10.3133/ofr20141005.

Any use of trade, product, or firm names is for descriptive purposes only and does not imply endorsement by the U.S. Government.

Although this report is in the public domain, permission must be secured from the individual copyright owners to reproduce any copyrighted material contained within this report. 


\section{Contents}

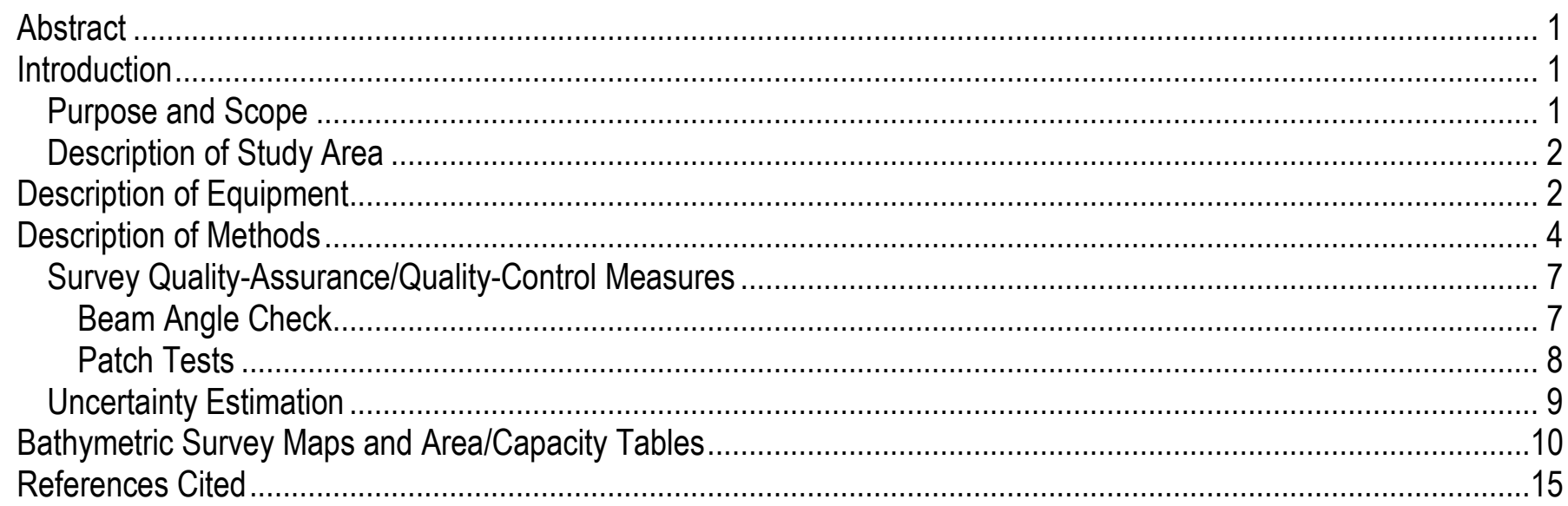

\section{Figures}

1. Map showing location of the study area on the water-supply reservoirs for the city of Cameron, Missouri.2

2. Photographs of the RESON SeaBat 7125-SV2 multibeam echosounder as viewed $A$, from the bottom and $B$, mounted on the port side of the U.S. Geological Survey boat.

3. Diagram showing the generalized sequence of survey lines used to maximize surveyed area and minimize data gaps during surveys on water-supply reservoirs for the city of Cameron, Missouri. $A$, First line is upstream along approximate centerline of reservoir; $B$, second line is downstream along edge of line 1 with overlap; and $C$, additional lines used to survey area not covered by lines 1 and 2 , propagating outward to the edges of the reservoir..

4. Map showing coverage and total propagated uncertainty of multibeam bathymetric survey data, and interpolated areas on water-supply reservoirs for the city of Cameron, Missouri .....

5. Diagram showing effects of $A$, timing offset for latency; and angular offsets for $B$, roll; $C$, pitch; and $D$, yaw on data from a multibeam echosounder.

6. Bathymetric map of Reservoir 1 near Cameron, Missouri, resulting from a survey on July 2, 2013, represented as a color-band image and as contours.

7. Bathymetric map of Reservoir 2 near Cameron, Missouri, resulting from a survey on July 1, 2013, represented as a color-band image and as contours.

8. Bathymetric map of Reservoir 3 near Cameron, Missouri, resulting from a survey on July 1, 2013, represented as a color-band image and as contours.

9. Bathymetric map of Grindstone Reservoir near Cameron, Missouri, resulting from a survey on July 2, 2013, represented as a color-band image and as contours. 


\section{Tables}

1. Results of a beam angle check from two check lines over a reference surface at Indian Lake near Cuba, Missouri, on September 4, 2012

2. Results of patch tests obtained while surveying Reservoir 3 and Grindstone Reservoir near Cameron, Missouri.

3. Total propagated uncertainty results for bathymetric data at a 3.28-foot (1-meter) grid spacing for each water-supply reservoir surveyed for the city of Cameron, Missouri.

4. Area and capacity at specified elevations for Reservoir 1 near Cameron, Missouri, on July 2, 2013....... 11

5. Area and capacity at specified elevations for Reservoir 2 near Cameron, Missouri, on July 1, 2013...... 12

6. Area and capacity at specified elevations for Reservoir 3 near Cameron, Missouri, on July 1, 2013...... 13

7. Area and capacity at specified elevations for Grindstone Reservoir near Cameron, Missouri, on July 2, 2013.

\section{Conversion Factors}

Inch/Pound to SI

\begin{tabular}{lcl}
\hline & \multicolumn{1}{c}{ Multiply } & \multicolumn{1}{c}{ To obtain } \\
\hline foot (ft) & Length & \\
mile (mi) & 0.3048 & meter (m) \\
& 1.609 & kilometer $(\mathrm{km})$ \\
\hline acre & Area & \\
acre & 4,047 & square meter $\left(\mathrm{m}^{2}\right)$ \\
acre & 0.4047 & hectare (ha) \\
acre & 0.4047 & square hectometer $\left(\mathrm{hm}^{2}\right)$ \\
\hline & 0.004047 & square kilometer $\left(\mathrm{km}^{2}\right)$ \\
\hline acre-foot (acre-ft) & Volume & \\
acre-foot (acre-ft) & 1,233 & cubic meter $\left(\mathrm{m}^{3}\right)$ \\
\hline
\end{tabular}

Vertical coordinate information is referenced to the North American Vertical Datum of 1988 (NAVD 88). Horizontal coordinate information is referenced to the North American Datum of 1983 (NAD 83). 


\title{
Bathymetric Surveys and Area/Capacity Tables of Water- Supply Reservoirs for the City of Cameron, Missouri, July 2013
}

\author{
By Richard J. Huizinga
}

\begin{abstract}
Years of sediment accumulation and dry conditions in recent years have led to the decline of water levels and capacities for many water-supply reservoirs in Missouri, and have caused renewed interest in modernizing outdated area/capacity tables for these reservoirs. The U.S. Geological Survey, in cooperation with the Missouri Department of Natural Resources, surveyed the bathymetry of the four water-supply reservoirs used by the city of Cameron, Missouri, in July 2013. The data were used to provide water managers with area/capacity tables and bathymetric maps of the reservoirs at the time of the surveys.
\end{abstract}

\section{Introduction}

Accumulation of sediment and dry conditions have led to the decline of water levels and capacities for many of the water-supply reservoirs in Missouri in the past (Richards, 2013). Often, these water-supply reservoirs had outdated area/capacity tables or had none at all, and managers of the water supplies were concerned that their reservoir's supply would not be adequate to meet their needs (Richards, 2013). For this reason, the U.S. Geological Survey (USGS), in cooperation with the Missouri Department of Natural Resources (MoDNR) and the U.S. Army Corps of Engineers, surveyed the bathymetry of 51 reservoirs in Missouri from July 2000 to May 2008 (Richards, 2013; Wilson and Richards, 2006). The data were used to provide water managers with area/capacity tables and bathymetric maps of the reservoirs at the time of the surveys.

Dry conditions in northern Missouri in late 2011 and throughout 2012 (National Oceanic and Atmospheric Administration, 2013) once again led to water-level declines for several water-supply reservoirs that were not surveyed previously by the USGS. The city of Cameron, Missouri, has four water-supply reservoirs for which the area/capacity tables were outdated. To provide the water-supply managers with updated information on the capacity of their water-supply reservoirs, the USGS, in cooperation with the MoDNR, surveyed the bathymetry of the four water-supply reservoirs on July 1-2, 2013, and provided updated area/capacity tables for these reservoirs.

\section{Purpose and Scope}

This report documents the equipment and methodology used to survey the bathymetry for four water-supply reservoirs used by the city of Cameron, Mo., and presents bathymetric maps and computed area and capacity tables for each reservoir. The total propagated uncertainty of the bathymetric surface for each reservoir also is presented. 


\section{Description of Study Area}

The study area covered Reservoirs 1-3 and Grindstone Reservoir, northwest of Cameron, Mo., in southeastern DeKalb County (fig. 1). Each reservoir was surveyed separately, and data for the project were collected and processed using the equipment and methods described below. The reservoirs were near their respective full-pool elevations during the surveys.

\section{Description of Equipment}

The bathymetry of each reservoir was determined using a high-resolution multibeam mapping system (MBMS). The various components of the MBMS used for this study are described in reports about studies on the Missouri and Mississippi Rivers in Missouri (Huizinga, 2010, 2011, 2012, 2013; Huizinga and others, 2010). The survey methods used to obtain the data for the Cameron reservoirs were similar to these other studies, as were the methods used to ensure data quality. A brief description of the equipment follows; a complete description of the various system components and methods used in this study is available in Huizinga (2010) and Huizinga and others (2010).

An MBMS is an integration of several individual components: the multibeam echosounder (MBES), a navigation and motion-sensing system, and a data-collection and -processing computer. The MBES that was used is the RESON SeaBatTM 7125-SV2 (fig. 2), operated at a frequency of 400 kilohertz $(\mathrm{kHz})$. The RESON SeaBat ${ }^{\mathrm{TM}} 7125-\mathrm{SV} 2$ is an updated version of the RESON SeaBat ${ }^{\mathrm{TM}} 7125$

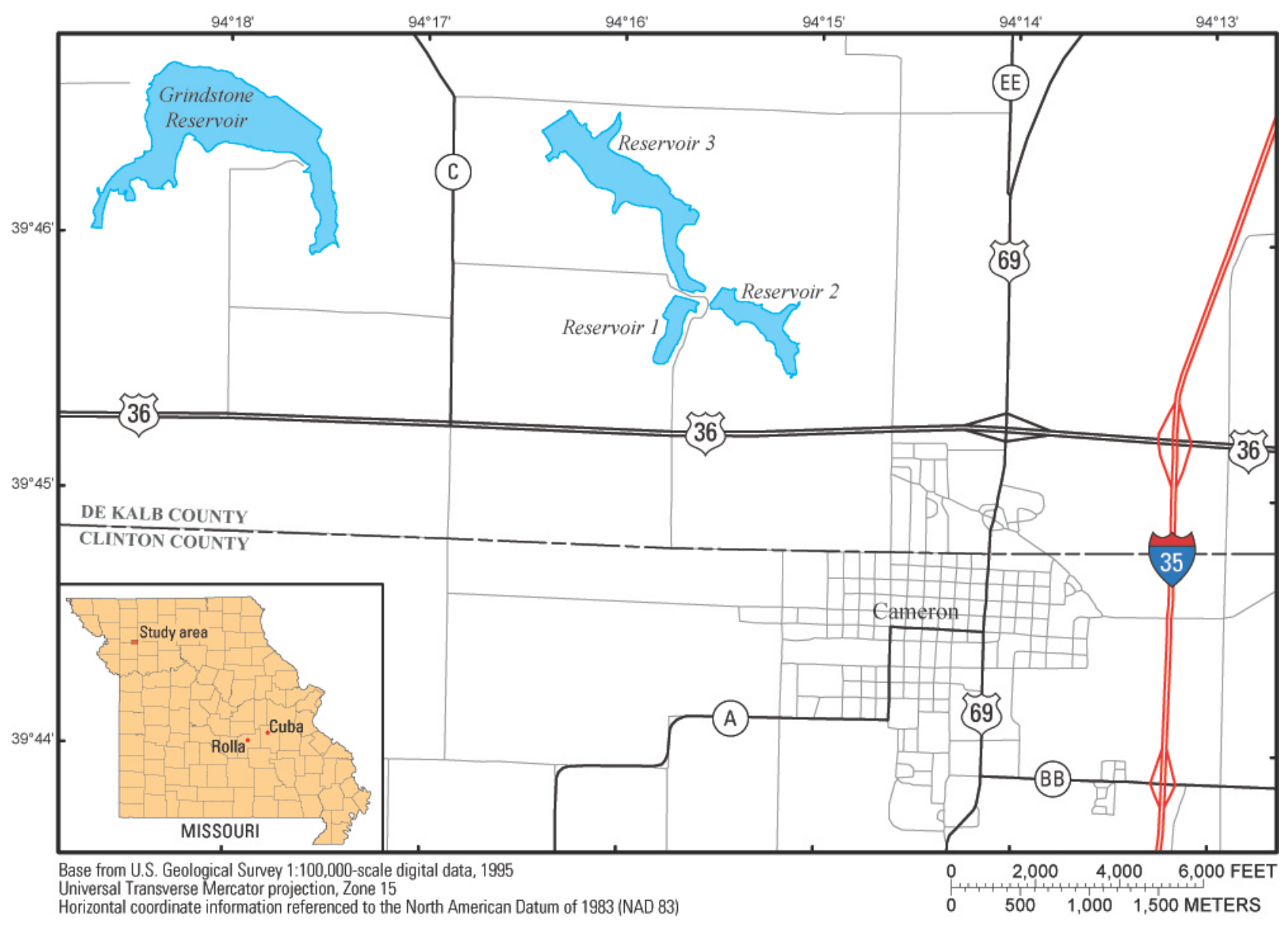

Figure 1. Location of the study area on the water-supply reservoirs for the city of Cameron, Missouri. 
and functions, but with a more streamlined sonar head, and stiffer, more compact head tilt bracket (fig. 2). The navigation and motion-sensing system that was used is the Applanix Position Orientation Solution for Marine Vessels (POS MVTM) WaveMaster system (hereinafter referred to as “the POS”). The navigation system locates the MBES in three-dimensional space, and the motion-sensing system measures the heave, pitch, roll, and heading of the vessel (and, thereby, the MBES) to accurately position the data received by the MBES.

For this survey, the MBES head was tilted at 30 degrees to port to enable acquisition of bathymetry data in the shallow areas near the banks, and to cover a wider swath of the bottom compared to when the head is not tilted.

A cellular network link with the Virtual Real-time Station (VRS) network [established and maintained by Missouri Department of Transportation (MoDOT)] was used to provide the real-time kinematic (RTK) differential corrections to the POS for the navigation and tide solution during the survey. Recorded values of the altitude of the survey boat based on the RTK solution indicated the reservoir level remained essentially constant for a given reservoir during the survey, as would be expected.

The data from the MBES and navigation and motion-sensing components were processed and integrated into a cohesive dataset for cleanup and visualization. A computer onboard the survey boat ran

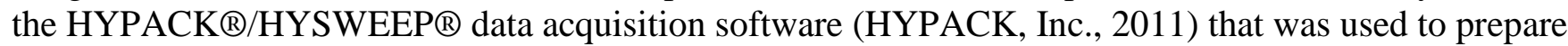
for the bathymetric surveys and collect the survey data. On completion of the survey, the acquired depth data were further processed in the CARIS HIPS and SIPS ${ }^{\circledR}$ processing software (CARIS, 2013) to apply sound velocity profile data, remove data spikes and other anomalies in the multibeam swath trace, georeference the data using the navigation and position solution data from the POS, and be visualized as
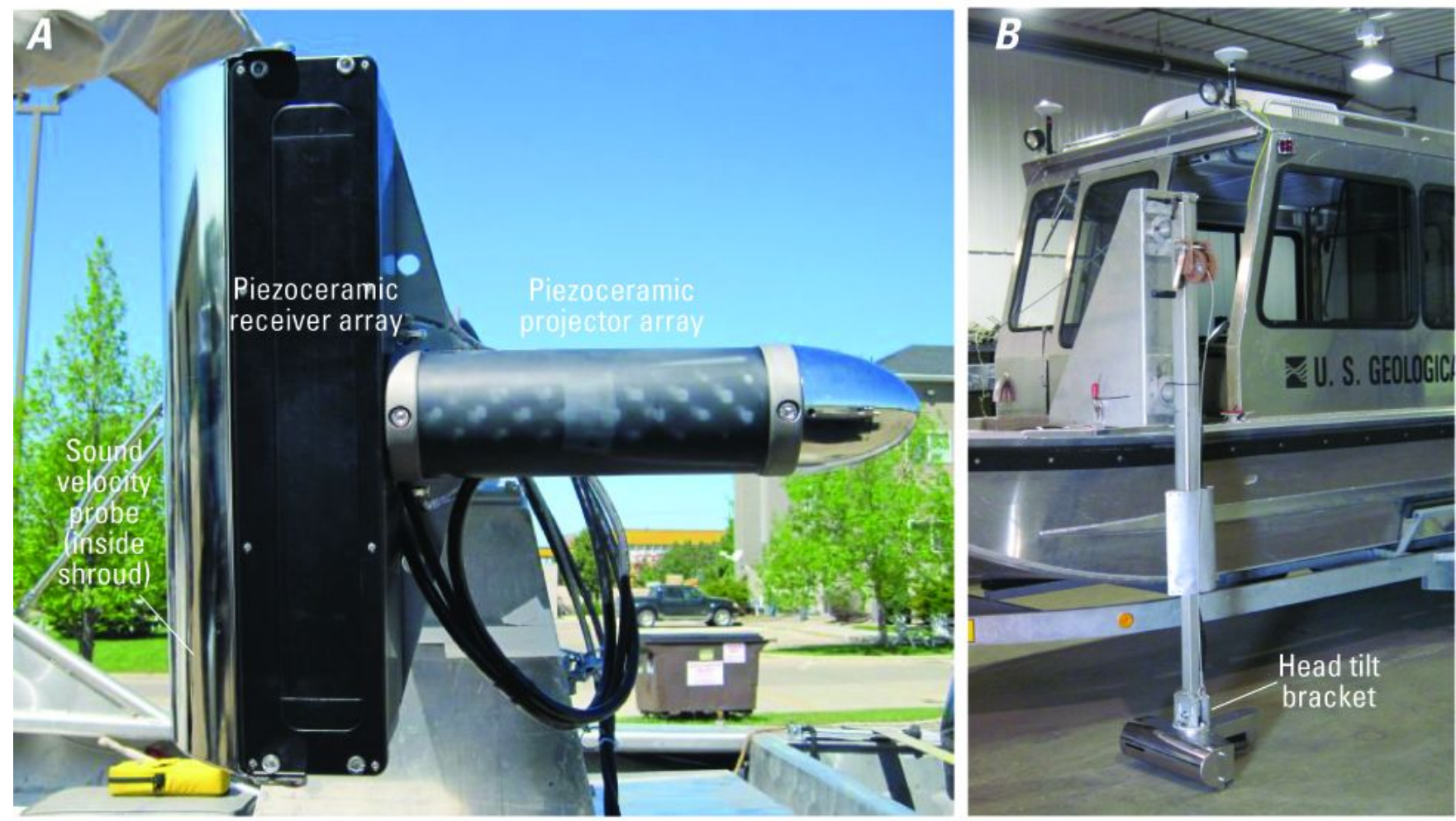

Figure 2. The RESON SeaBat 7125-SV2 multibeam echosounder as viewed $A$, from the bottom and $B$, mounted on the port side of the U.S. Geological Survey boat. 
a gridded surface or a point cloud. The finalized, georeferenced elevation data were output to a commadelimited file averaged to a 3.28-foot [ft; 1-meter (m)] horizontal data resolution, and were compiled into a geographic information system (GIS) database using the ArcGIS software (Environmental Systems Research Institute, 2013).

\section{Description of Methods}

In a reservoir, it is not unusual for the speed of sound to change both temporally and as a result of water temperature variations with depth (stratification within the water column). Although sound velocity data are collected at the MBES head throughout the survey, the changes in the speed of sound with depth need to be known to accurately determine the depths acquired by the MBES. Therefore, a sound velocity profile was measured in the deepest part of the reservoir at the beginning and end of each survey, and applied during post-processing in CARIS HIPS and SIPS ${ }^{\circledR}$.

With the exception of Reservoir 3, the perimeters of the reservoirs were taken from watersurface shorelines in the Light Detection and Ranging (lidar) data for the area obtained in May 2011 and released by the U.S. Natural Resources Conservation Service (NRCS) in February 2013 (Missouri Spatial Data Information Service, 2013). The lidar data were collected at a 3.28-ft (1-m) nominal post spacing, with a stated vertical accuracy of $0.28 \mathrm{ft}(0.085 \mathrm{~m})$. The elevations of the lidar shorelines were similar to the water-surface elevations of the three reservoirs on the dates of the surveys, and represent a continuous reservoir shoreline that could not be acquired using the MBMS. Furthermore, the lidar shoreline elevations were near the full-pool elevations of the three reservoirs. Therefore, the lidar shorelines were used as the perimeter of the three reservoirs, and reservoir-bottom data were interpolated between the edge of the data acquired with the MBMS and the perimeter, using techniques detailed in Wilson and Richards (2006).

Within each reservoir, bathymetric data were obtained by "painting" the bottom of the reservoir in a series of survey passes (fig. 3). In Reservoirs 1-3, the first line was taken in an upstream direction along the approximate centerline of the reservoir (fig. 3A), and a second line was taken in a downstream direction along the approximate centerline (fig. $3 B$ ). The third and fourth lines were taken in a similar manner, with an attempt to overlap the previous survey line swath on that side (fig. $3 C$ ). Additional lines were surveyed, radiating outward from the centerline of the reservoir, as needed, until most of the reservoir bed was covered. Additional lines of data were collected in coves, if possible. Care was exercised to overlap the survey swaths to minimize areas requiring interpolation of data (fig. 4). Much of the area requiring interpolation around the perimeter of Reservoirs 1-3 was filled with aquatic vegetation, and was not able to be surveyed with the MBES.

Because of substantial areas of submerged tree stumps in Grindstone Reservoir and overall shape of the reservoir, a longitudinal centerline could not be surveyed. Rather, the perimeter of the reservoir was surveyed along a line roughly $150 \mathrm{ft}$ from the bank (similar to lines 3 and 4 in fig. 3C), and a second line was surveyed in the opposite direction with the MBES aiming towards the center of the reservoir. Areas with substantial numbers of submerged tree stumps were obtained by surveying the perimeter of the area with the MBES aiming towards the center, and a second line in the opposite direction with the MBES aiming away. When possible, the survey boat was navigated among the flooded timber and slowly rotated to obtain a circular fan of data; however, this often caused the MBES to strike submerged tree stumps, so this practice was minimized to limit damage to the survey equipment. Any remaining areas were surveyed with alternating directions. In this way, substantial parts of the reservoir were able to be surveyed, with minimal areas requiring data interpolation (fig. 4). 


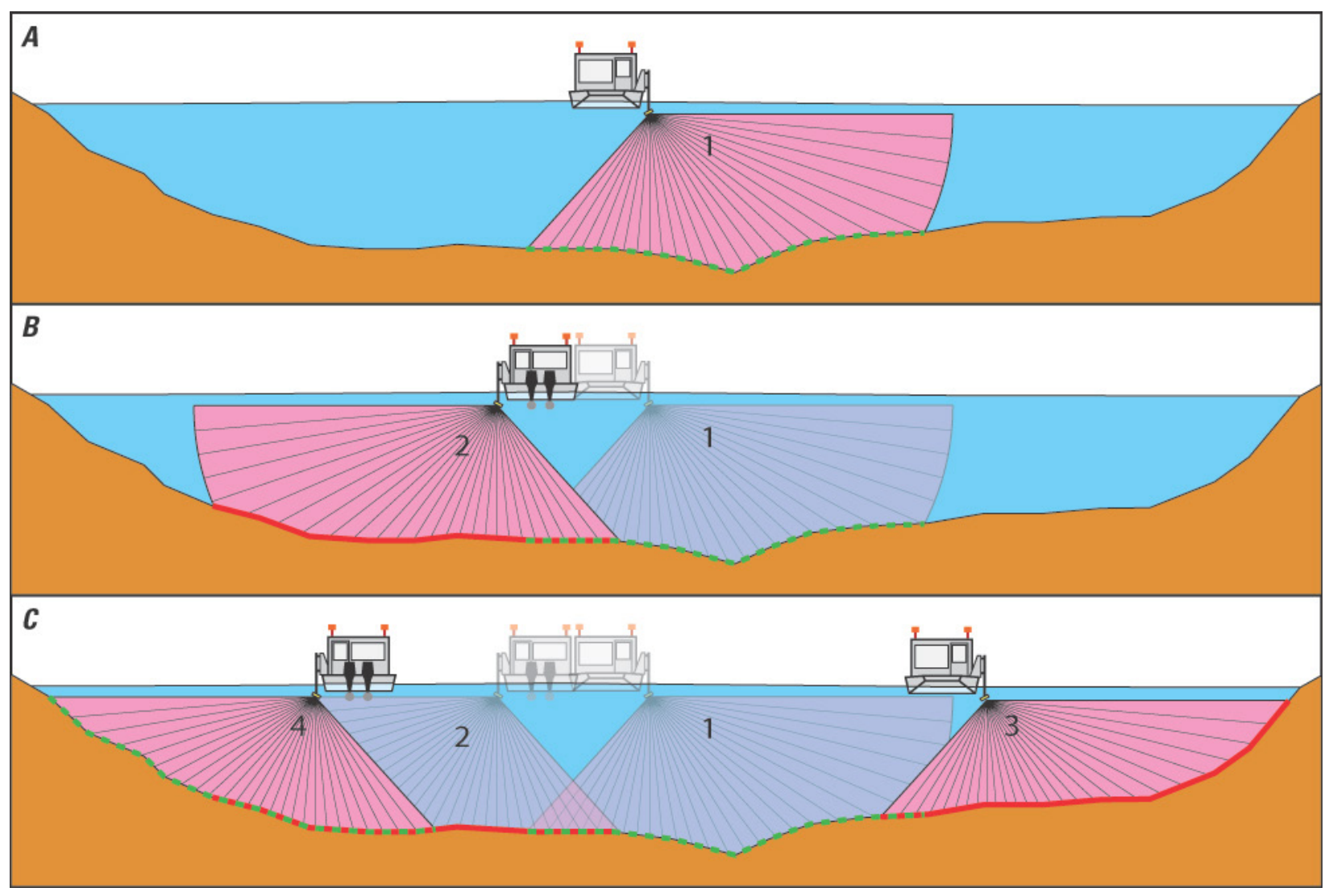

Figure 3. Generalized sequence of survey lines used to maximize surveyed area and minimize data gaps during surveys on water-supply reservoirs for the city of Cameron, Missouri. $A$, First line is upstream along approximate centerline of reservoir; $B$, second line is downstream along edge of line 1 with overlap; and $C$, additional lines used to survey area not covered by lines 1 and 2 , propagating outward to the edges of the reservoir. Illustration is oriented looking downstream.

Using these techniques, nearly full coverage of the bottom and substantial overlap in some areas was achieved for large sections of each reservoir; however, occasional survey data gaps occurred where the water was too shallow to operate the MBES effectively, or when the survey swaths were not close enough to each other. Larger data gaps were eliminated with additional survey passes when possible.

For Reservoir 3, the water-surface elevation during the survey was almost $2 \mathrm{ft}$ higher than the lidar shoreline elevation, and was near the full-pool elevation for that reservoir. Therefore, the lidar elevation data were used above the lidar shoreline elevation up to the surveyed water-surface elevation of $910.6 \mathrm{ft}$. Reservoir-bottom data were interpolated between the edge of the data acquired with the MBMS and the lidar data around the perimeter of Reservoir 3, using techniques detailed in Wilson and Richards (2006).

Reference marks were established at each of the reservoirs with survey-grade Global Navigation Satellite Systems (GNSS) using methods documented in Rydlund and Densmore (2012) and Wilson and Richards (2006). Horizontal and vertical coordinates of the reference marks were determined using real-time GNSS methods with RTK differential corrections from the MoDOT VRS network, and verified and localized using confident geodetic control. The reference marks were not used to verify horizontal or vertical position of the bathymetric survey points, but can be used to determine the watersurface elevation of a given reservoir. 


\section{EXPLANATION}

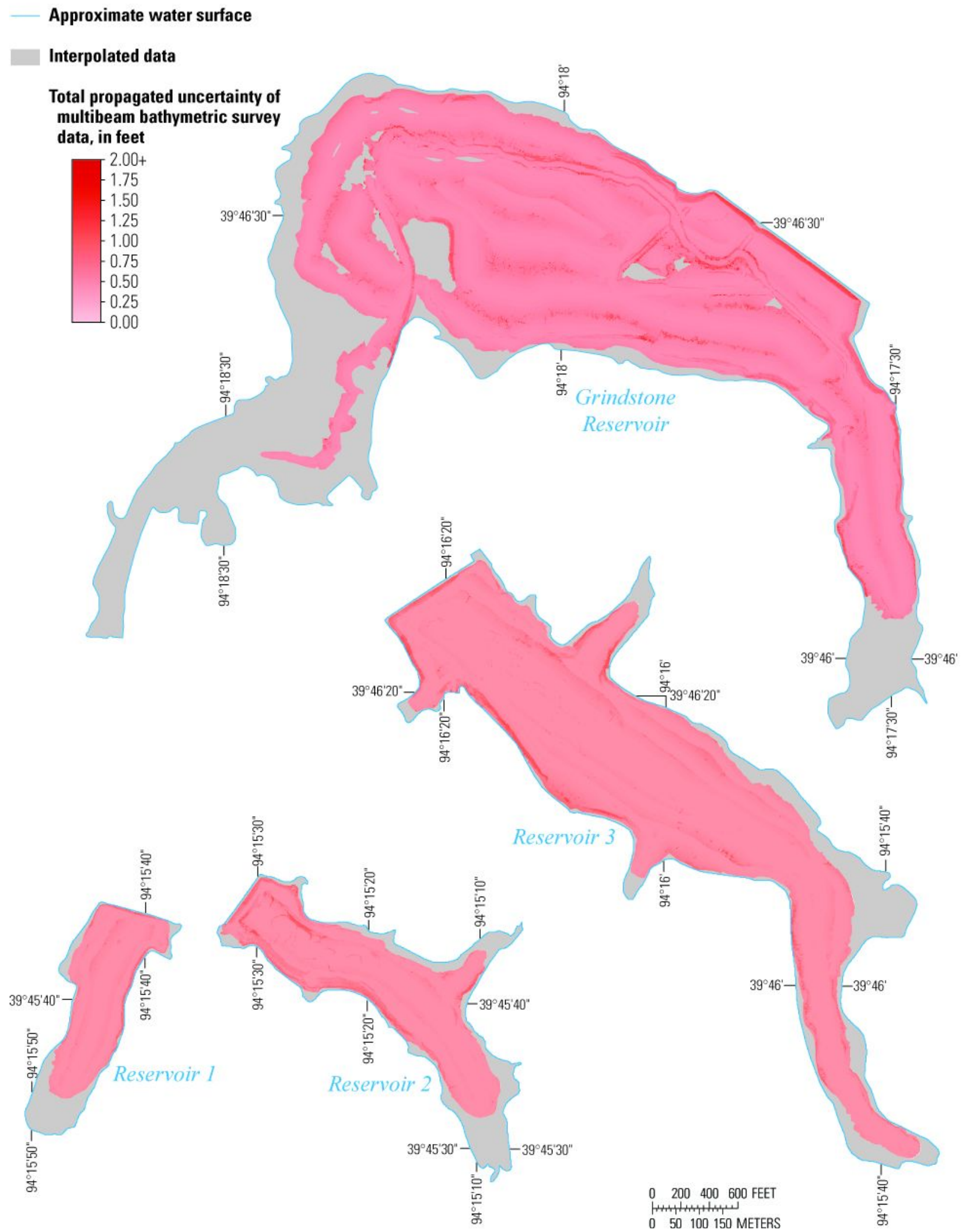

Figure 4. Coverage and total propagated uncertainty of multibeam bathymetric survey data, and interpolated areas on water-supply reservoirs for the city of Cameron, Missouri 


\section{Survey Quality-Assurance/Quality-Control Measures}

For the MBMS, the principal quality-assurance measures were assessed in real time during the survey. The MBMS operator continuously assessed the quality of the collected data during the survey, making visual observations of across-track swaths (such as convex, concave, or skewed bed returns in flat, smooth bottoms), noting data quality flags and alarms from the MBES and the POS, and noting comparisons between adjacent overlapping swaths. In addition to the real-time quality-assurance assessments during the survey, beam angle checks and a suite of patch tests were executed to ensure quality data were acquired from the MBMS.

\section{Beam Angle Check}

A beam angle check is used to determine the accuracy of the depth readings obtained by the outer beams [greater than 25 degrees from nadir (vertical)] of the MBES (U.S. Army Corps of Engineers, 2004), which may change with time as a result of inaccurate sound velocities, physical configuration changes, and overall depth being surveyed. The HYPACK ${ }^{\circledR} / \mathrm{HYSWEEP}^{\circledR}$ software has a utility that develops a statistical assessment of the quality of the outer beams compared to a reference surface (HYPACK, Inc., 2011). On September 4, 2012, a reference surface was created for a part of Indian Lake near Cuba, Mo., and check lines were run across the reference surface. The results of this beam angle check (table 1) were within the recommended performance standards utilized by the U.S. Army Corps of Engineers for hydrographic surveys for all angles (U.S. Army Corps of Engineers, 2004), permitting the use of the full sonar swath.

Table 1. Results of a beam angle check from two check lines over a reference surface at Indian Lake near Cuba, Missouri, on September 4, 2012.

\begin{tabular}{ccccc} 
[<, less than; --, no data] & & & \\
\hline $\begin{array}{c}\text { Beam angle } \\
\text { limit }\end{array}$ & $\begin{array}{c}\text { Maximum } \\
\text { outlier } \\
\text { (degrees) }\end{array}$ & $\begin{array}{c}\text { Mean } \\
\text { difference } \\
\text { (feet) }\end{array}$ & $\begin{array}{c}\text { Standard } \\
\text { deviation } \\
\text { (feet) }\end{array}$ & $\begin{array}{c}\text { 95-percent } \\
\text { confidence } \\
\text { (feet) }\end{array}$ \\
\hline 20 & 0.82 & 0.13 & 0.16 & 0.30 \\
25 & 0.82 & 0.13 & 0.16 & 0.30 \\
30 & 0.82 & 0.13 & 0.16 & 0.30 \\
35 & 0.82 & 0.10 & 0.16 & 0.30 \\
40 & 0.82 & 0.10 & 0.16 & 0.30 \\
45 & 0.82 & 0.10 & 0.16 & 0.30 \\
50 & 0.82 & 0.10 & 0.16 & 0.30 \\
55 & 0.82 & 0.10 & 0.13 & 0.30 \\
60 & 0.82 & 0.10 & 0.13 & 0.30 \\
65 & 0.82 & 0.13 & 0.16 & 0.30 \\
70 & 0.82 & 0.16 & 0.16 & 0.33 \\
75 & 0.82 & 0.16 & 0.16 & 0.33 \\
\hline & & Performance standards ${ }^{\mathrm{a}}$ & -- & $<0.50$ \\
\hline & 1.00 & $<0.20$ & -- & Met \\
\hline & Met & Met & $-2004)$, & \\
\hline
\end{tabular}

${ }^{\mathrm{a} P e r f o r m a n c e ~ s t a n d a r d ~ c h e c k ~ v a l u e s ~ a r e ~ f r o m ~ U . S . ~ A r m y ~ C o r p s ~ o f ~ E n g i n e e r s ~(2004), ~ t a b l e ~}$ 3-1. 


\section{Patch Tests}

Patch tests are a series of dynamic calibration tests that are used to check for subtle variations in the orientation and timing of the MBES with respect to the POS and real-world coordinates. The patch tests are used to determine timing offsets caused by latency between the MBES and the POS, and angular offsets to roll, pitch, and yaw caused by the alignment of the transducer head (fig. 5). These offsets are assumed to be constants for a given survey, barring an event that causes the mount to change, such as striking a submerged object. The offsets determined in the patch test are applied when processing the data collected during a given survey.

A patch test was done in Reservoir 3 near the beginning of the surveys on July 1, 2013, and a second test was done on July 2, after the MBES unit struck multiple submerged logs while surveying Grindstone Reservoir, causing the mount to bend (table 2).

For this study, there was no measured timing offset (table $2 ; \Delta t=0$, fig. 5), which is consistent with latency test results for similar equipment configurations used in other surveys (Huizinga, 2010, 2011, 2012, 2013; Huizinga and others, 2010; Richard Huizinga, U.S. Geological Survey, unpub. data, 2013). The measured angular offset for roll was 26.90 degrees in both patch tests (table 2), which is consistent with the angular offset for roll value determined for this boat and sonar head during previous recent surveys (Richard Huizinga, unpub. data, 2013). From the first patch test, the measured angular

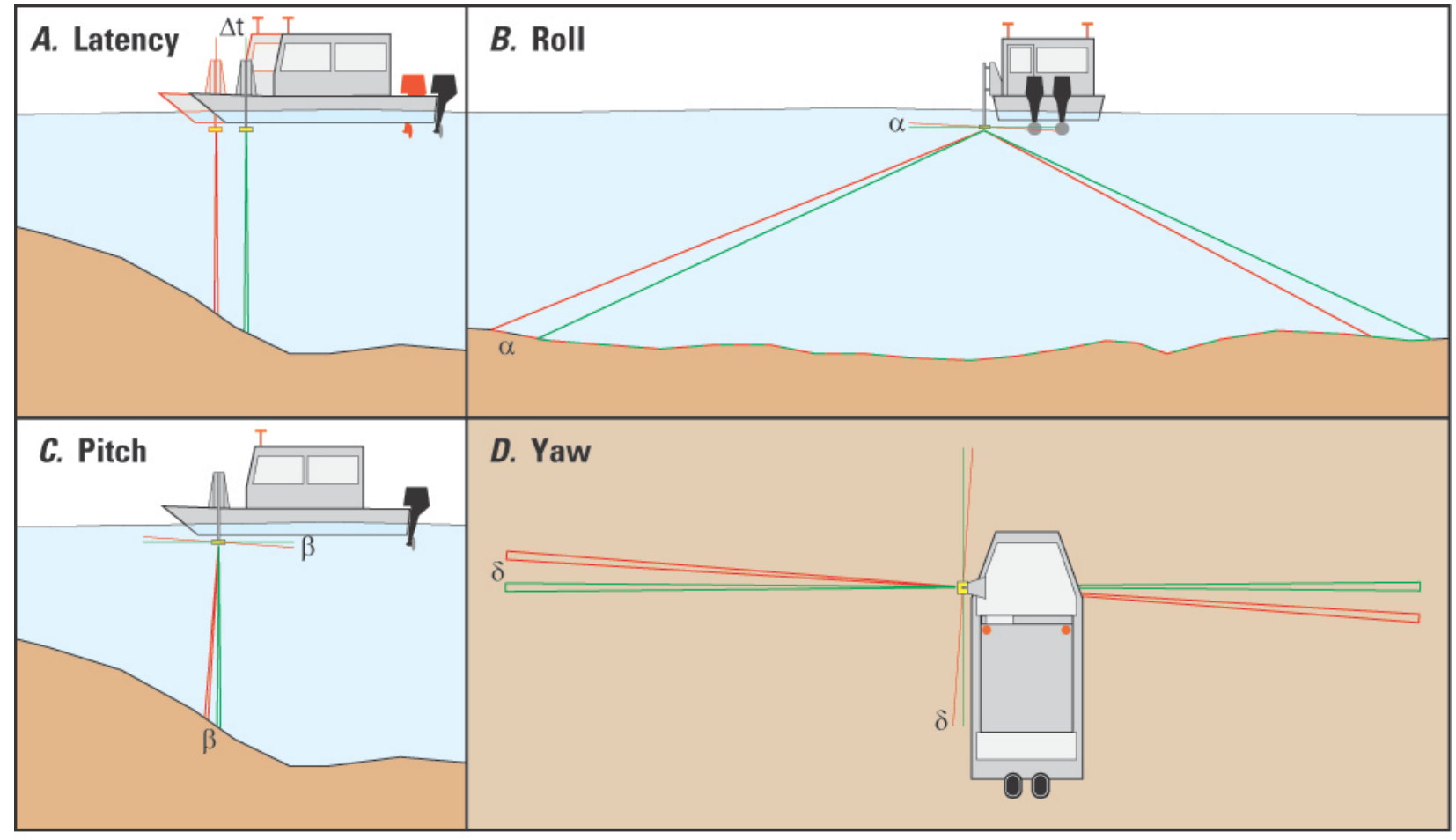

\section{EXPLANATION}

- Actual bottom Measured bottom

$\Delta t \quad$ Timing offset for latency between the multibeam echosounder and Global Navigation

Satellite System components of the navigation and motion-sensing system

$\alpha$ Angular offset for roll of the transducer head along the longitudinal axis of the boat

$\beta$ Angular offset for pitch of the transducer head along the lateral axis of the boat

$\delta \quad$ Angular offset for yaw of the transducer head about the vertical axis

Figure 5. Effects of $A$, timing offset for latency; and angular offsets for $B$, roll; $C$, pitch; and $D$, yaw on data from a multibeam echosounder. 
offset for pitch was -1.50 degrees and the measured angular offset for yaw was 2.20 degrees (table 2). These values are consistent with pitch and yaw values determined for this boat and sonar head during previous recent surveys (Richard Huizinga, unpub. data, 2013). From the second patch test, the measured angular offset for pitch was 0.00 degrees, and the measured angular offset for yaw was 2.50 degrees (table 2). The change from the first to the second offset values for pitch and yaw is the result of striking several submerged logs, which caused the MBES mount to bend. It was noted in Huizinga (2010) that a sensitivity analysis of the four offsets implied that the ultimate position of surveyed points in three-dimensional space was least sensitive to the angular offset for yaw, whereas it was most sensitive to the angular offset for roll.

Table 2. Results of patch tests obtained while surveying Reservoir 3 and Grindstone Reservoir near Cameron, Missouri.

[sec, seconds; deg, degrees]

\begin{tabular}{cccccc}
\hline & Timing & $\begin{array}{c}\text { Angular } \\
\text { offset for }\end{array}$ & $\begin{array}{c}\text { Angular } \\
\text { offset for } \\
\text { Date of }\end{array}$ & $\begin{array}{c}\text { Angular } \\
\text { offset for }\end{array}$ & \\
test & $(\mathrm{sec})$ & roll & pitch & yaw & Location \\
\hline $07 / 01 / 13$ & 0 & 26.90 & -1.50 & 2.20 & Reservoir 3 \\
$07 / 02 / 13$ & 0 & 26.90 & 0.00 & 2.50 & Grindstone Reservoir \\
\hline
\end{tabular}

\section{Uncertainty Estimation}

The Combined Uncertainty Bathymetric Estimator (CUBE) method (Calder and Mayer, 2003), as implemented in the CARIS HIPS and SIPS ${ }^{\circledR}$ software (CARIS, 2013), was used to estimate total propagated uncertainty (TPU) for the 3.28-ft $(1-\mathrm{m})$ gridded surface of each survey area. The CUBE method allows all random system component uncertainties and resolution effects to be combined and propagated through the data processing steps, which provides a robust estimate of the spatial distribution of possible uncertainty within the survey area (Czuba and others, 2011). Thus, the TPU of a point is a measure of the accuracy to be expected for such a point, when all relevant error sources are accounted for (Czuba and others, 2011). Statistics of TPU for each reservoir are shown in table 3, and the spatial distribution of TPU observed in each reservoir is shown in figure 4.

Table 3. Total propagated uncertainty results for bathymetric data at a 3.28-foot (1-meter) grid spacing for each water-supply reservoir surveyed for the city of Cameron, Missouri.

[TPU, total propagated uncertainty; ft, feet]

\begin{tabular}{|c|c|c|c|c|c|c|c|c|c|}
\hline \multirow[b]{2}{*}{ Reservoir } & \multirow{2}{*}{$\begin{array}{l}\text { Number of } \\
\text { points }\end{array}$} & \multirow{2}{*}{$\begin{array}{c}\text { Maximum } \\
\text { value of } \\
\text { TPU } \\
\text { (ft) }\end{array}$} & \multirow{2}{*}{$\begin{array}{l}\text { Mean } \\
\text { value of } \\
\text { TPU } \\
\text { (ft) }\end{array}$} & \multirow{2}{*}{$\begin{array}{l}\text { Median } \\
\text { value of } \\
\text { TPU } \\
\text { (ft) }\end{array}$} & \multirow{2}{*}{$\begin{array}{c}\text { Standard } \\
\text { deviation } \\
\text { of TPU } \\
\text { (ft) }\end{array}$} & \multicolumn{4}{|c|}{$\begin{array}{c}\text { Percent of bathymetry points with TPU } \\
\text { value less than }\end{array}$} \\
\hline & & & & & & $2.00 \mathrm{ft}$ & $1.00 \mathrm{ft}$ & $0.50 \mathrm{ft}$ & $0.25 \mathrm{ft}$ \\
\hline Reservoir 1 & 49,445 & 1.59 & 0.49 & 0.47 & 0.07 & 100.0 & 99.9 & 81.4 & 0.0 \\
\hline Reservoir 2 & 92,519 & 1.70 & 0.51 & 0.47 & 0.10 & 100.0 & 99.7 & 74.9 & 0.0 \\
\hline Reservoir 3 & 302,013 & 2.16 & 0.50 & 0.47 & 0.09 & 100.0 & 99.5 & 77.0 & 0.0 \\
\hline Grindstone & 538,851 & 4.74 & 0.51 & 0.48 & 0.11 & 100.0 & 98.9 & 65.4 & 0.0 \\
\hline
\end{tabular}


The largest TPU of the four surveys was $4.74 \mathrm{ft}$ (table 3); however, TPU values of this magnitude typically were observed near high-relief features, such as along banks or large submerged objects, or towards the outermost beam parts of the survey swaths (fig. 4). Most of the TPU values (98.9 percent or more) were less than $1.00 \mathrm{ft}$ (table 3), and almost two-thirds (65.4 percent or more) of the survey data had TPU values of $0.50 \mathrm{ft}$ or less (table 3). The accuracy of the bathymetric surface of the water-supply reservoirs for the city of Cameron were not evaluated in areas that were not surveyed with the MBMS.

\section{Bathymetric Survey Maps and Area/Capacity Tables}

As explained in the "Description of Equipment" and "Description of Methods" sections above, the bathymetric data were processed to apply the offsets determined from the patch tests and to remove data anomalies in the multibeam swaths. The bathymetric data were then averaged to a grid at a resolution of 3.28-ft (1-m), which was combined with interpolated data between the multibeam data and the lidar shoreline or the lidar data up to the MBMS surveyed shoreline. These data were used to generate a raster surface of the bottom for each reservoir. The raster surface for each reservoir is shown using a color bar graduated to elevation, and using cartographically edited contours generated from the surface (figs. 6-9). Area and capacity were computed at 2-ft increments to estimate the stage capacity for each reservoir, and are presented on the corresponding reservoir figures as tables 4-7. The capacity of the reservoir shown in the tables is an estimate of the storage at various elevations based on the bathymetric surface; however, the stated volume of water may not all be available for use because of various limiting factors, such as the elevation of the water intakes (below which water cannot be used). 


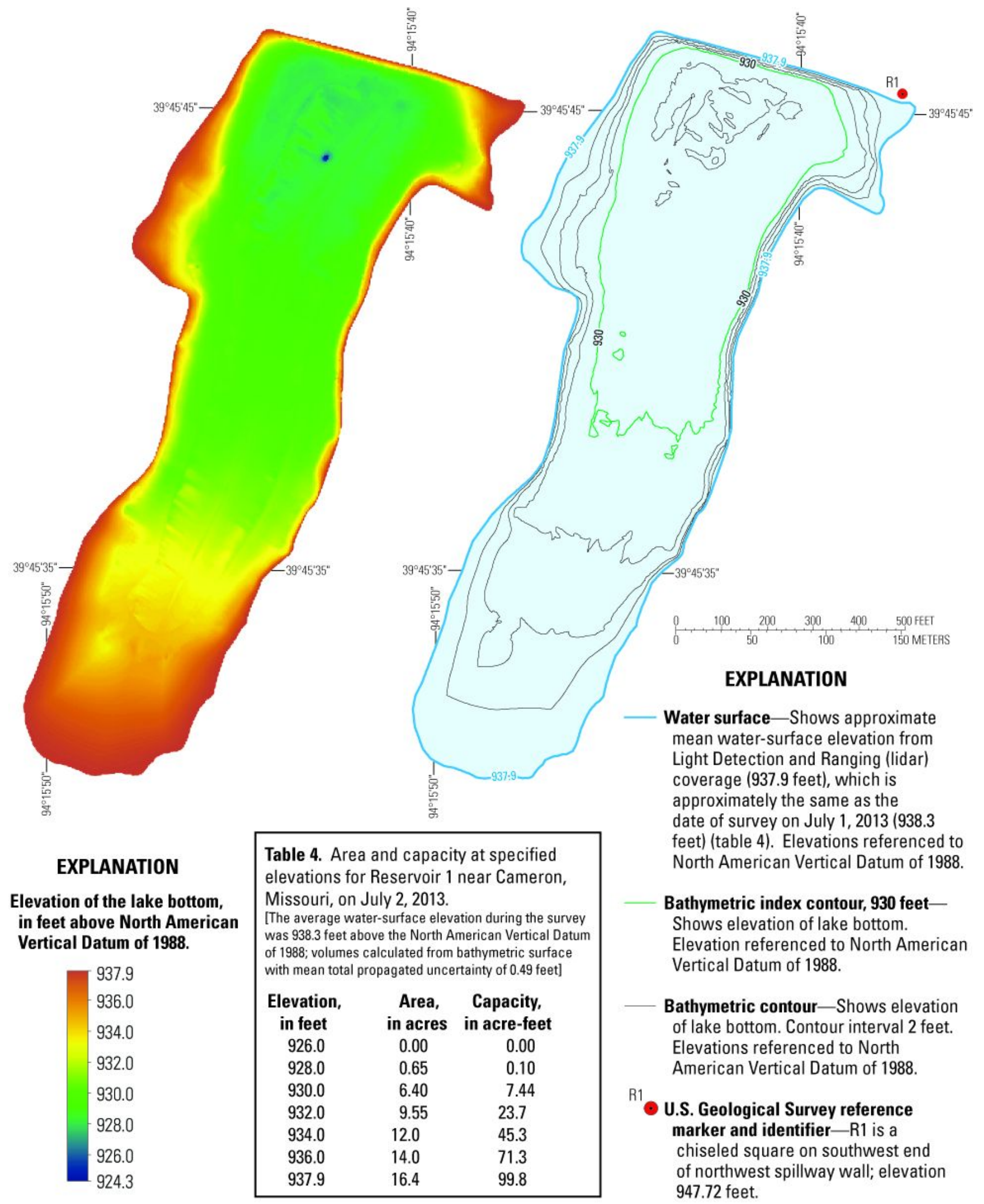

Figure 6. Bathymetric map of Reservoir 1 near Cameron, Missouri, resulting from a survey on July 2, 2013, represented as a color-band image and as contours. 


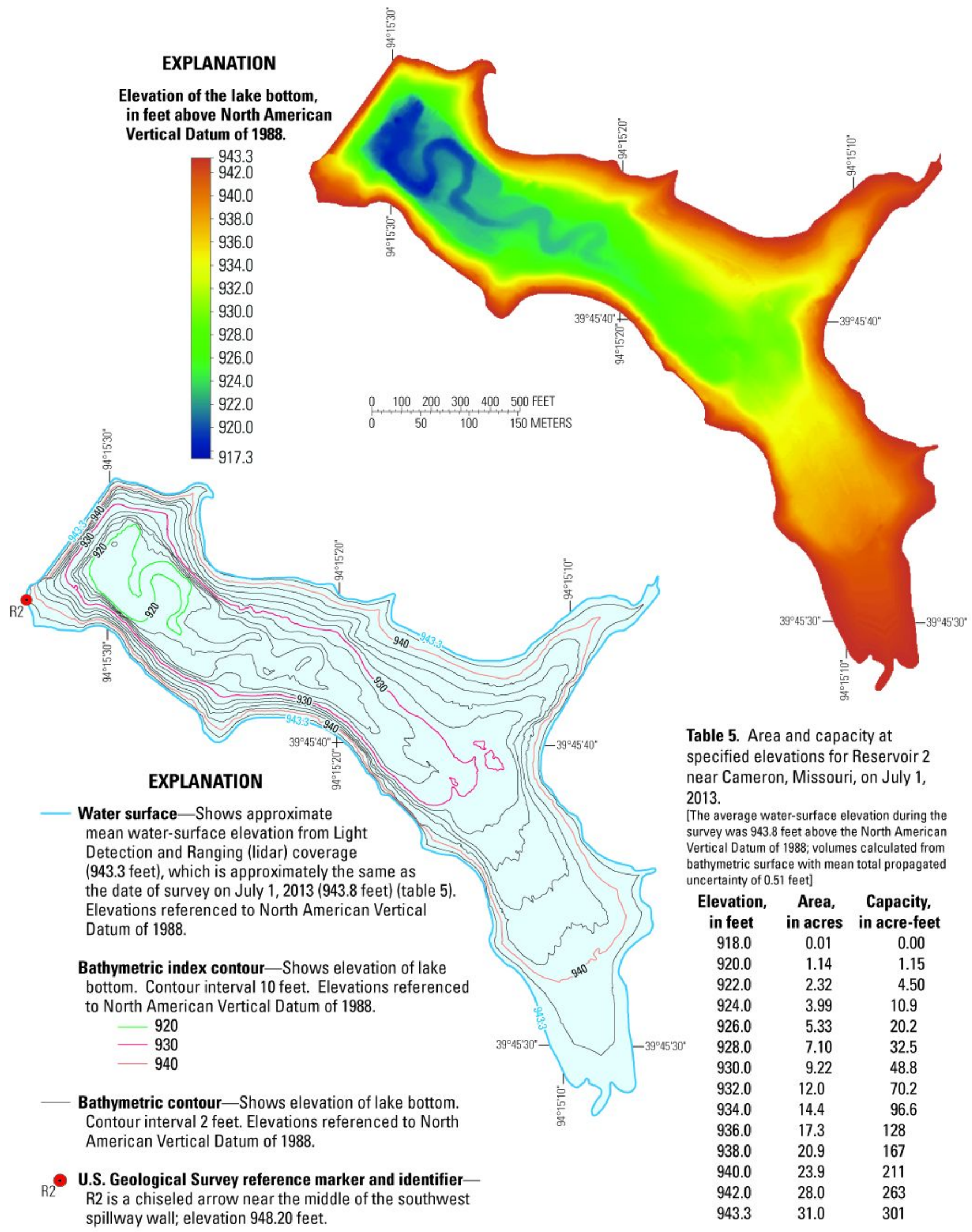

Figure 7. Bathymetric map of Reservoir 2 near Cameron, Missouri, resulting from a survey on July 1, 2013, represented as a color-band image and as contours. 


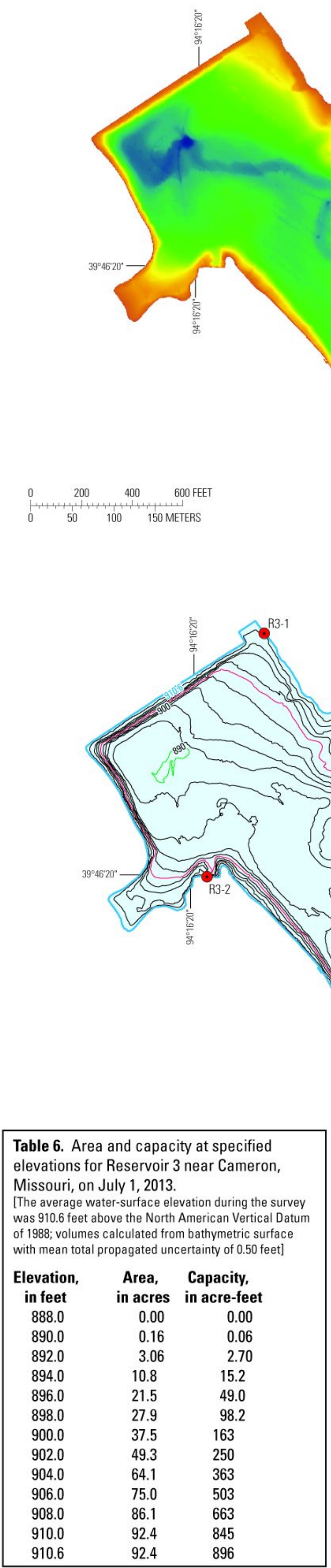

EXPLANATION

Elevation of the lake bottom,

in feet above North American

Vertical Datum of 1988.

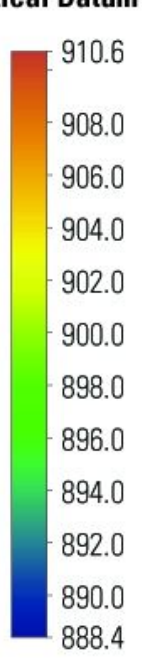

Table 6 . Area and capacity at specified elevations for Reservoir 3 near Cameron, Missouri, on July 1, 2013

The average water-surface elevation during the survey of 1988; volumes calculated from bathymetric surface with mean total propagated uncertainty of 0.50 feet

\begin{tabular}{ccc}
$\begin{array}{c}\text { Elevation, } \\
\text { in feet }\end{array}$ & $\begin{array}{c}\text { Area, } \\
\text { in acres }\end{array}$ & $\begin{array}{c}\text { Capacity, } \\
\text { in acre-feet }\end{array}$ \\
888.0 & 0.00 & 0.00 \\
890.0 & 0.16 & 0.06 \\
892.0 & 3.06 & 2.70 \\
894.0 & 10.8 & 15.2 \\
896.0 & 21.5 & 49.0 \\
898.0 & 27.9 & 98.2 \\
900.0 & 37.5 & 163 \\
902.0 & 49.3 & 250 \\
904.0 & 64.1 & 363 \\
906.0 & 75.0 & 503 \\
908.0 & 86.1 & 663 \\
910.0 & 92.4 & 845 \\
910.6 & 92.4 & 896 \\
\hline
\end{tabular}

Water surface-Shows approximate mean water-surface
elevation on the date of survey on July 1, 2013 (910.6 feet) Elevation on the date of survey on July 1, 2013 (910.6 feet). of 1988 .

Bathymetric index contour-Shows elevation of lake bottom. Contour interval 10 feet. Elevations referenced to North American Vertical Datum of 1988. Elevation 910 not shown, as it is essentially the same as water-surface elevation.

$$
\begin{array}{r}
-890 \\
-\quad 900
\end{array}
$$

Bathymetric contour-Shows elevation of lake bottom. Contour interval 2 feet. Elevations referenced to North American Vertical Datum of 1988 .

- U.S. Geological Survey reference marker and identifier-

R3-1 is a chiseled arrow near middle of northeast spillway wall elevation 918.42 feet.

R3-2 is a chiseled arrow on west wingwall of pump house elevation 913.67 feet.
80.0

006.0

02.0

900.0

898.0

396.0

88.4 




Figure 9. Bathymetric map of Grindstone Reservoir near Cameron, Missouri, resulting from a survey on July 2, 2013, represented as a color-band image and as contours. 


\section{References Cited}

Calder, B.R., and Mayer, L.A., 2003, Automatic processing of high-rate, high-density multi-beam echosounder data: Geochemistry, Geophysics, Geosystems, v. 4, p. 1,048.

CARIS, 2013, CARIS HIPS and SIPS 8.0 user guide: Fredericton, New Brunswick, Canada, 560 p.

Czuba, J.A., Best, J.L., Oberg, K.A., Parsons, D.R., Jackson, P.R., Garcia, M.H., and Ashmore, P., 2011, Bed morphology, flow structure, and sediment transport at the outlet of Lake Huron and in the Upper Saint Clair River: Journal of Great Lakes Research, v. 37, no. 3, p. 480-493.

Environmental Systems Research Institute, 2013, ArcGIS: accessed July 2013, at http://www.esri.com/software/arcgis/.

Huizinga, R.J., 2010, Bathymetric surveys at highway bridges crossing the Missouri River in Kansas City, Missouri, using a multibeam echo sounder, 2010: U.S. Geological Survey Scientific Investigations Report 2010-5207, 61 p. (Also available at http://pubs.usgs.gov/sir/2010/5207/.)

Huizinga, R.J., 2011, Bathymetric surveys at highway bridges crossing the Missouri and Mississippi Rivers near St. Louis, Missouri, 2010: U.S. Geological Survey Scientific Investigations Report 20115170, 75 p. (Also available at http://pubs.usgs.gov/sir/2011/5170/.)

Huizinga, R.J., 2012, Bathymetric and velocimetric surveys at highway bridges crossing the Missouri River in and into Missouri during summer flooding, July-August 2011: U.S. Geological Survey Scientific Investigations Report 2012-5204, 166 p. (Also available at http://pubs.usgs.gov/sir/2012/5204/.)

Huizinga, R.J., 2013, Results of repeat bathymetric and velocimetric surveys at the Amelia Earhart Bridge on U.S. Highway 59 over the Missouri River at Atchison, Kansas, 2009-2013: U.S. Geological Survey Scientific Investigations Report 2013-5177, 50 p., http://pubs.usgs.gov/sir/2013/5177.

Huizinga, R.J., Elliott, C.M., and Jacobson, R.B., 2010, Bathymetric and velocimetric survey and assessment of habitat for pallid sturgeon on the Mississippi River in the vicinity of the proposed Interstate 70 Bridge at St. Louis, Missouri: U.S. Geological Survey Scientific Investigations Report 2010-5017, 28 p. Also available at http://pubs.usgs.gov/sir/2010/5017/.)

HYPACK, Inc., 2011, HYPACK ${ }^{\circledR}$ Hydrographic survey software user's manual 02/11: Middletown, Conn., 1,582 p.

Missouri Spatial Data Information Service, 2013, MOLiDAR DEM file download tool: accessed November 2013, at http://www.msdis.missouri.edu/data/lidar/download/modem.html.

National Oceanic and Atmospheric Administration, 2013, Advanced hydrologic prediction service precipitation analysis: National Weather Service, accessed November 2013, at http://water.weather.gov/precip/index.php.

Richards, J.M., 2013, Bathymetric surveys of selected lakes in Missouri-2000-2008: U.S. Geological Survey Open-File Report 2013-1101, 9 p. with appendix, http://pubs.usgs.gov/of/2013/1101.

Rydlund, P.H., Jr., and Densmore, B.K., 2012, Methods of practice and guidelines for using surveygrade global navigation satellite systems (GNSS) to establish vertical datum in the United States Geological Survey: U.S. Geological Survey Techniques and Methods, book 11, chap. D1, 102 p. with appendixes.

U.S. Army Corps of Engineers, 2004, Engineering and design-Hydrographic surveying: Washington D.C., U.S. Army Corps of Engineers, manual no. EM 1110-2-1003, 560 p.

Wilson, G.L., and Richards, J.M., 2006, Procedural documentation and accuracy assessment of bathymetric maps and area/capacity tables for small reservoirs: U.S. Geological Survey Scientific Investigations Report 2006-5208, 24 p. plus oversize figs. 